\section{Turfgrass Seed and Sod Establishment on Soil Amended with Biosolid Compost}

\author{
Douglas T. Linde ${ }^{1}$ and Lawrence D. Hepner
}

\begin{abstract}
AdDitional Index words. kentucky bluegrass, Poa pratensis, sewage sludge, salinity, ammonium

SUMMARY. Using composted biosolid waste as a soil amendment for turfgrass is becoming a common method for disposing of municipal waste. This study was conducted to evaluate turfgrass seed and sod establishment on subsoil amended with various rates of biosolid compost. To a soil that had its A-horizon removed, biosolid compost derived from sewage sludge was incorporated at rates of 0 , 132,270 , and 402 yard $^{3} /$ acre. A fifth treatment included a single application of fertilizer at time of sowing. Kentucky bluegrass (Poa pratensis) was seeded immediately after treatment application. The treatments were repeated on an adjacent area using kentucky bluegrass sod. For 1.5 years, turfgrass percent cover, color, density, and weeds were evaluated. Overall, the compost performed well as a soil amendment for turfgrass. A 2- to 3-inch depth of compost appeared to be the best incorporation rate for the soil and compost used in this study. High salinity and excessive ammonium nitrogen $\left(\mathrm{NH}_{4}-\mathrm{N}\right)$ levels in the compost-amended soil at the time of establishment caused a 2- to 3-week delay in seed and sod establishment. After the 2 to 3 weeks, the compost-amended plots outperformed the one-time fertilized plots in turfgrass color and density. Turf managers may want to account for the delay in establishment when incorporating a 60-day-cured compost.
\end{abstract}

$\mathrm{T}$ To ease the burden of waste disposal, many waste authorities and municipalities have started composting their sewage sludge. These biosolid composts are then used as soil amendments. Amending soil low in organic matter before turfgrass establishment has been one use of these composts. Researchers have found that turfgrass growth is enhanced when using composted biosolids (Barker, 1993; Landschoot and McNitt, 1994; Sikora and Enkiri, 1999). Markham et al. (1998) determined that turfgrass grown in sand-based rootzone mix amended with biosolid compost established more quickly and yielded significantly deeper roots and improved color than turf grown in peat-amended rootzone mix. The enhanced growth in these studies was attributed to changes in soil physical and/or chemical properties. In addition, some researchers have found that biosolid compost use can reduce the severity of certain turfgrass diseases (Boulter et al., 2002; Craft and Nelson, 1996). The effects that biosolid-amended soil had on turfgrass establishment have varied.

Department of Agronomy and Environmental Science, Delaware Valley College, 700 E. Butler Ave., Doylestown, PA 18901

Supported by Camden County Municipal Utilities Authority, Camden, NJ 08101.

${ }^{1}$ Associate Professor. E-mail: Linded@devalcol.edu
Barker (1993) determined that biosolid compost initially inhibited turfgrass seedling establishment. O'Brien and Barker (1996a, 1996b) found that high levels of $\mathrm{NH}_{4}-\mathrm{N}$ and soluble salts in an immature biosolid compost inhibited turfgrass seed germination and establishment. Conversely, Landschoot and McNitt (1994) did not observe any seedling inhibition during turfgrass establishment on a biosolid-amended soil. Among those limited studies, researchers did not investigate compost incorporation rates into soil, nor did they assess establishment from sod. The objective of this research was to evaluate turfgrass seed and sod establishment on subsoil amended with various rates of biosolid compost.

\section{Materials and methods}

The study was conducted at the Turfgrass Research Facility on the Delaware Valley College campus,
Doylestown, Pa. Plots were constructed in Sept. 1998 on a Lansdale soil (coarse-loamy, mixed, mesic Typic Hapludult). The A-horizon of the site was removed using a bulldozer in order to simulate a scenario in which a contractor strips the topsoil from a new site and does not replace it. The remaining subsoil is often low in organic matter and nutrients and is unsuitable for turfgrass. The remaining sandy loam B-horizon soil was tilled to a 4 - to 6-inch depth using a rotary tiller. Plot elevations were altered accordingly so that final plot elevations were uniform following the addition of various depths of compost. Each plot was $5 \times 6 \mathrm{ft}$ in dimension with a $\mathrm{l}-\mathrm{ft}$ untreated border between plots. Treatments were arranged using a randomized complete-block design with four replications. Treatments were: control (no compost), 1 inch of compost (132 yard $^{3} /$ acre $), 2$-inch depth of compost (270 yard 3 /acre), 3 -inch depth of compost (402 yard $^{3}$ ) acre), and fertilizer. Compost used was a 60-d-old composted biosolid material processed by the Camden County Municipal Utilities Authority, Camden, N.J. The compost facility consisted of a series of in-vessel composters called tunnel reactors that were designed by PWT-Waste Solutions, Inc., Houston, Texas. Raw biosolid sludge was mixed with wood chips and placed at one end of the tunnel. For the next $31 \mathrm{~d}$ the material was aerated with forced air while being automatically pushed to the other end of the tunnel. The compost was then stored in a covered storage building until use.

Immediately after applying compost treatments on 2 Sept. 1998, all plots were tilled to a 4- to 6-inch depth, then hand-raked to final grade. Soil samples were taken from the top 5 inches of each plot. After soil samples were taken, a 19-26-5 fertil$\operatorname{izer}(19 \mathrm{~N}-11.4 \mathrm{P}-4.1 \mathrm{~K})$ was applied to the fertilizer treatment at a rate that delivered 44,26, and $10 \mathrm{lb} /$ acre of $\mathrm{N}$,

\begin{tabular}{llll}
\hline $\begin{array}{l}\text { Units } \\
\begin{array}{l}\text { To convert U.S. to SI, } \\
\text { multiply by }\end{array}\end{array}$ & U.S. unit & SI unit & $\begin{array}{l}\text { To convert SI to U.S., } \\
\text { multiply by }\end{array}$ \\
\hline 0.3048 & $\mathrm{ft}$ & $\mathrm{m}$ & 3.2808 \\
9.2903 & $\mathrm{ft}^{2}$ & $\mathrm{dm}^{2}$ & 0.1076 \\
2.5400 & inch $(\mathrm{es})$ & $\mathrm{cm}$ & 0.3937 \\
25.4000 & inch $(\mathrm{es})$ & $\mathrm{mm}$ & 0.0394 \\
1.1209 & $\mathrm{lb} / \mathrm{acre}$ & $\mathrm{kg} \cdot \mathrm{ha}^{-1}$ & 0.8922 \\
1 & mmho/cm & $\mathrm{dS} \cdot \mathrm{m}^{-1}$ & 1 \\
1 & $\mathrm{ppm}$ & $\mathrm{mg} \cdot \mathrm{kg}^{-1}$ & 1 \\
1.8893 & yard $/ \mathrm{acre}$ & $\mathrm{m} \cdot \mathrm{ha}^{-1}$ & 0.5293
\end{tabular}


$\mathrm{P}$, and $\mathrm{K}$, respectively. The fertilizer contained $14 \%$ urea-N, $5 \% \mathrm{NH}_{4}-\mathrm{N}$ and slowly available methylene urea-N, P derived from monoammonium phosphate, and Kfrom potassium sulfate. To determine baseline levels of nutrients, $\mathrm{pH}$, and electrical conductivity (EC) [ 1 soil: 2 water extract method by volume (Dellavalle, 1992)] before the study, samples of compost were tested by Camden County Municipal Utilities Authority on six dates in 1997.

Plots were seeded with 'Touchdown' kentucky bluegrass at $130 \mathrm{lb} /$ acre. All seeded areas were covered with straw at a rate that covered $50 \%$ of the soil surface. Plots were irrigated with approximately 0.2 inch of water three times per week until germination, after which the plots were not irrigated. The same set of treatments were applied to an adjacent area, however plots were sodded with kentucky bluegrass instead of seeding. All plots were mowed approximately weekly to a 2.5 -inch height using a rotary mower. Plots did not receive any supplemental fertilizer over the duration of the study.

Approximately once per month, the turfgrass in each plot was visually evaluated for percent vegetative cover, plant density, color, and percent weeds. Percent vegetative cover was measured using a scale from 0 to 100 with 0 $=$ bare soil and $100=$ complete soil coverage with plants. Plant density was measured using a scale from 1 to 9 with $\mathrm{l}=$ no plants and $9=$ maximum plant density for the turfgrass species [at least 200 shoots $/ \mathrm{dm}^{2}$ for kentucky bluegrass (Beard, 1973)]. Color was measured using a scale from 1 to 9 with $\mathrm{l}=$ straw brown and $9=$ dark green. Percent weeds was measured using a scale from 0 to 100 with $0=$ no weeds and $100=$ complete coverage by weeds. Data were analyzed using the general linear model of SPSS statistical software version 10.0 (SPSS, Inc., Chicago). Treatment means within each date were compared using Duncan's multiple range test with a 0.05 level of significance.

On 2 Sept. 1998, 10 Sept. 1999, and 20 June 2000, soil samples were taken from the top 5 inches from each plot. Samples were analyzed by the Pennsylvania State University Agricultural Analytical Services Laboratory for nitrate nitrogen $\left(\mathrm{NO}_{3}-\mathrm{N}\right)$ (specific ion electrode), $\mathrm{NH}_{4}-\mathrm{N}$ (specific ion electrode), Total-N (combustion with Fisons NAl500 Elemental Analyzer;
Fisons Instruments, Danvers, Mass.), $\mathrm{pH}$ (water method), acidity, cation exchange capacity (CEC), percent organic matter (loss on ignition), soluble salts measured as electrical conductivity [1 soil: 2 water extract method by volume (Dellavalle, 1992)], and available $\mathrm{P}, \mathrm{K}$, magnesium $(\mathrm{Mg})$, and calcium (Ca) (Mehlich 3).

\section{Results and discussion}

Compost samples had an average $\mathrm{pH}$ of 5.49 and $\mathrm{EC}$ of $4.7 \mathrm{dS} \cdot \mathrm{m}^{-1}$ $(\mathrm{mmho} / \mathrm{cm})$. Concentrations of nutrients included: $1.3 \%$ dry weight Total $\mathrm{N}, 109 \mathrm{mg} \cdot \mathrm{kg}^{-1} \mathrm{NO}_{3}-\mathrm{N}, 3539 \mathrm{mg} \cdot \mathrm{kg}^{-1}$
$\mathrm{NH}_{4}-\mathrm{N}, 3545 \mathrm{mg} \cdot \mathrm{kg}^{-1} \mathrm{P}, 2010 \mathrm{mg} \cdot \mathrm{kg}^{-1}$ $\mathrm{K}$, $11.5 \mathrm{mg} \cdot \mathrm{kg}^{-1} \mathrm{Ca}, 5.6 \mathrm{mg} \cdot \mathrm{kg}^{-1} \mathrm{Mg}$, $0.3 \mathrm{mg} \cdot \mathrm{kg}^{-1}$ boron, $14 \mathrm{mg} \cdot \mathrm{kg}^{-1}$ iron, $0.4 \mathrm{mg} \cdot \mathrm{kg}^{-1}$ manganese, $4.7 \mathrm{mg} \cdot \mathrm{kg}^{-1}$ copper, $14 \mathrm{mg} \cdot \mathrm{kg}^{-1}$ zinc, $0.5 \mathrm{mg} \cdot \mathrm{kg}^{-1}$ molybdenum, $1.8 \mathrm{mg} \cdot \mathrm{kg}^{-1}$ aluminum, $17 \mathrm{mg} \cdot \mathrm{kg}^{-1}$ sodium, and $68 \mathrm{mg} \cdot \mathrm{kg}^{-1}$ chlorine.

For most months during the study period precipitation amounts were below the 30-year average for each respective month (Fig. 1). A drought occurred from June through Aug. 1999. Air temperatures were similar to the 30-year average for each month (Fig. 2).

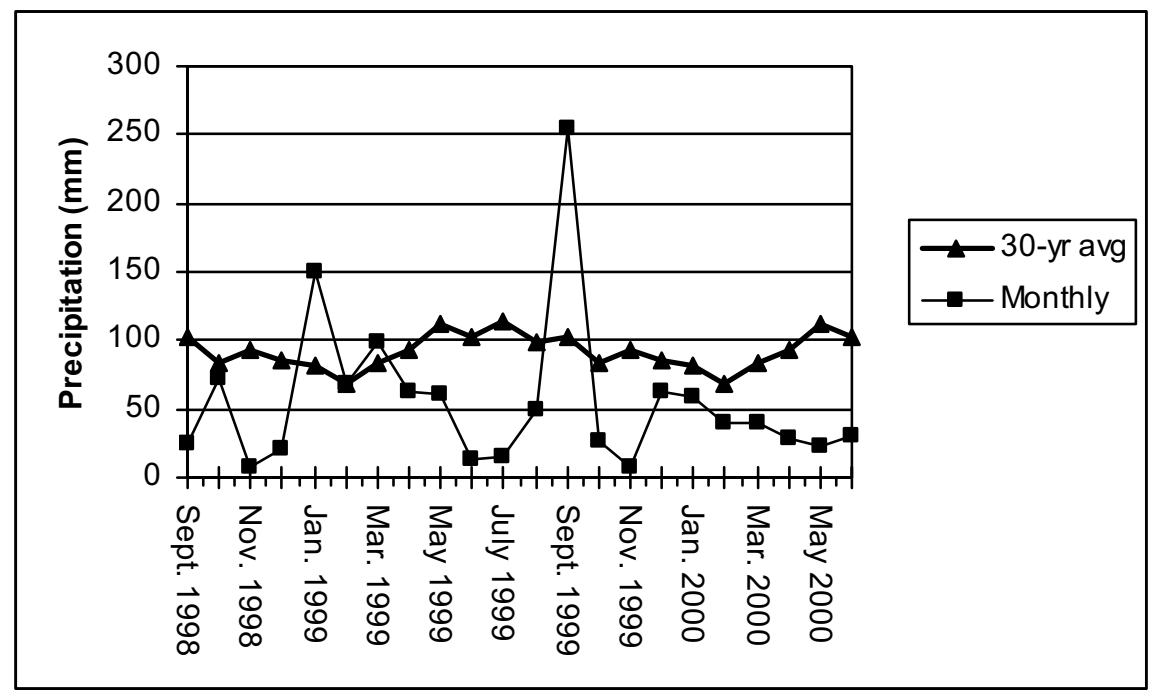

Fig. 1. Comparison of monthly precipitation from Sept. 1998 through June 2000 with the average monthly precipitation from 1961-90. Willow Grove Naval Air Weather Station, Willow Grove, Pa. $(1 \mathrm{~mm}=0.0394$ inch $)$.

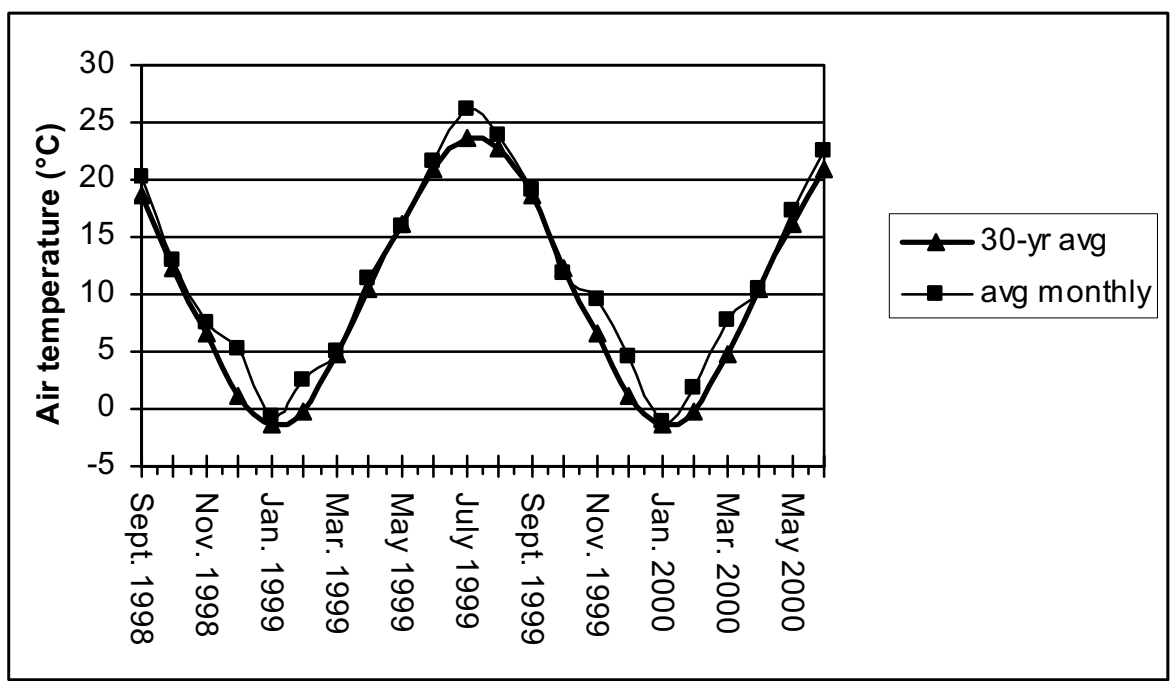

Fig. 2. Comparison of average monthly air temperature from Sept. 1998 through June 2000 with the average monthly air temperature from 1961-90. Willow Grove Naval Air Weather Station, Willow Grove, Pa. $\left[\left(1.8 \times{ }^{\circ} \mathrm{C}\right)+32=\right.$ $\left.{ }^{\circ} \mathrm{F}\right]$. 


\section{Establishment study from seed}

Percent vegetative cover was a measure of the establishment rate of the turfgrass seed. On 26 Sept. 1998, $24 \mathrm{~d}$ after seeding, the plots that received the one-time fertilizer treatment had significantly higher percent cover $(54 \%)$ than all other treatments (Table 1 ). In addition, percent cover was similar for all compost treatments and the control. Thus, the fertilizer-treated plots were quickest to establish. The 3 -inch and 2 -inch compost-treated plots were the next quickest to establish. On 22 Oct. 1998, percent cover for the 3 -inch treatment was similar to fertilizer. For the remainder of 1998, percent cover for the fertilizer treatment did not increase while percent cover for all compost treatments continued to increase to levels equal or greater than the fertilizer treatment. On 13 Apr. 1999, percent cover for the compost-treated plots became significantly greater than the fertilizer-treated plots. This trend continued for the remainder of the study. On 14 Sept. 1999, all rates of compost resulted in similar percent cover values. Before this date, the 2inch and 3 -inch rates often had similar values that were higher than the 1 -inch rate. On all dates the control treatment had the lowest percent cover.

On most dates, the compost treatments had significantly higher color ratings than the fertilizer and control treatments (Table 2). During the first year, the 2 -inch and 3 -inch compost rates had similar color ratings. By 14 Oct. 1999, the 3 -inch plots had consistently higher color ratings than the 2 -inch plots and the 2 -inch plots had higher ratings than the 1 -inch plots. These trends were interrupted during June, July, and August 1999 because of an extended drought. On 14 June 1999 , the 3 -inch rate actually had the lowest color rating of all treatments. Conditions created by the high amount of compost in the soil and the drought caused the turfgrass of the 3 -inch plots to visibly enter dormancy earlier.

Composted treatments consistently had higher plant density ratings than the control and fertilizer treatments (Table 3 ). The 2 -inch and 3 -inch plots eventually developed higher densities than the 1 -inch plots. On most dates the control treatment contained the highest percent weeds (Table 4). Composted plots tended to have fewer weeds than the fertilized

Table 1. Mean percent vegetative cover on plots seeded with kentucky bluegrass on 2 Sept. 1998 as influenced by fertilizer and three rates of incorporated compost.

\begin{tabular}{lccccc}
\hline & \multicolumn{5}{c}{ Mean vegetative cover (\%) } \\
\cline { 2 - 6 } Date $^{y}$ & Control & Fertilizer & \multicolumn{1}{c}{ Depth of applied compost (inches) } \\
\hline 26 Sept. 1998 & $34 \mathrm{a}^{\mathrm{x}}$ & $54 \mathrm{c}$ & $37 \mathrm{ab}$ & $39 \mathrm{ab}$ & $44 \mathrm{~b}$ \\
9 Oct. 1998 & $37 \mathrm{a}$ & $76 \mathrm{~d}$ & $54 \mathrm{~b}$ & $61 \mathrm{c}$ & $66 \mathrm{c}$ \\
22 Oct. 1998 & $45 \mathrm{a}$ & $82 \mathrm{c}$ & $72 \mathrm{~b}$ & $72 \mathrm{~b}$ & $77 \mathrm{bc}$ \\
6 Nov. 1998 & $46 \mathrm{a}$ & $82 \mathrm{~b}$ & $81 \mathrm{~b}$ & $77 \mathrm{~b}$ & $80 \mathrm{~b}$ \\
6 Dec. 1998 & $47 \mathrm{a}$ & $82 \mathrm{~b}$ & $84 \mathrm{bc}$ & $85 \mathrm{bc}$ & $89 \mathrm{c}$ \\
12 Mar. 1999 & $47 \mathrm{a}$ & $82 \mathrm{~b}$ & $84 \mathrm{bc}$ & $85 \mathrm{bc}$ & $89 \mathrm{c}$ \\
13 Apr. 1999 & $46 \mathrm{a}$ & $72 \mathrm{~b}$ & $81 \mathrm{c}$ & $79 \mathrm{bc}$ & $90 \mathrm{~d}$ \\
10 May 1999 & $41 \mathrm{a}$ & $56 \mathrm{~b}$ & $89 \mathrm{c}$ & $96 \mathrm{c}$ & $98 \mathrm{c}$ \\
14 June 1999 & $50 \mathrm{a}$ & $71 \mathrm{~b}$ & $84 \mathrm{c}$ & $94 \mathrm{~d}$ & $97 \mathrm{~d}$ \\
10 July 1999 & $50 \mathrm{a}$ & $71 \mathrm{~b}$ & $84 \mathrm{c}$ & $94 \mathrm{~d}$ & $97 \mathrm{~d}$ \\
10 Aug. 1999 & $50 \mathrm{a}$ & $71 \mathrm{~b}$ & $84 \mathrm{c}$ & $94 \mathrm{~d}$ & $97 \mathrm{~d}$ \\
14 Sept. 1999 & $67 \mathrm{a}$ & $80 \mathrm{~b}$ & $97 \mathrm{c}$ & $99 \mathrm{c}$ & $97 \mathrm{c}$ \\
14 Oct. 1999 & $57 \mathrm{a}$ & $84 \mathrm{~b}$ & $97 \mathrm{c}$ & $99 \mathrm{c}$ & $100 \mathrm{c}$ \\
12 Nov. 1999 & $62 \mathrm{a}$ & $82 \mathrm{~b}$ & $99 \mathrm{c}$ & $99 \mathrm{c}$ & $100 \mathrm{c}$ \\
20 Dec. 1999 & $62 \mathrm{a}$ & $82 \mathrm{~b}$ & $99 \mathrm{c}$ & $99 \mathrm{c}$ & $100 \mathrm{c}$ \\
17 May 2000 & $70 \mathrm{a}$ & $85 \mathrm{~b}$ & $98 \mathrm{c}$ & $100 \mathrm{c}$ & $100 \mathrm{c}$ \\
14 June 2000 & $52 \mathrm{a}$ & $70 \mathrm{~b}$ & $97 \mathrm{c}$ & $100 \mathrm{c}$ & $100 \mathrm{c}$ \\
\hline
\end{tabular}

${ }^{2} 1$ inch $=2.54 \mathrm{~cm}$.

yplots were seeded on 2 Sept. 1998 following treatment.

'Within rows, means followed by same letter are not significantly different according to Duncan's multiple range test $(P=0.05)$

Table 2. Mean color of kentucky bluegrass on various dates after seeding on 2 Sept. 1998 as influenced by fertilizer and three rates of incorporated compost.

\begin{tabular}{|c|c|c|c|c|c|}
\hline \multirow[b]{3}{*}{$\underline{\text { Date }}$} & \multicolumn{5}{|c|}{ Mean color $(\%)^{\mathrm{z}}$} \\
\hline & \multirow[b]{2}{*}{ Control } & \multirow[b]{2}{*}{ Fertilizer } & \multicolumn{3}{|c|}{ Depth of applied compost (inches) } \\
\hline & & & 1 & 2 & 3 \\
\hline 22 Oct. 1998 & $5.0 \mathrm{a}^{\mathrm{x}}$ & $7.0 \mathrm{~b}$ & $7.5 \mathrm{~d}$ & $7.4 \mathrm{~cd}$ & $7.3 \mathrm{c}$ \\
\hline 6 Nov. 1998 & $5.0 \mathrm{a}$ & $6.9 \mathrm{~b}$ & $6.9 \mathrm{~b}$ & $8.4 \mathrm{c}$ & $8.8 \mathrm{c}$ \\
\hline 6 Dec. 1998 & $6.5 \mathrm{~b}$ & $5.1 \mathrm{a}$ & $5.6 \mathrm{a}$ & $8.0 \mathrm{c}$ & $8.9 \mathrm{~d}$ \\
\hline 12 Mar. 1999 & $4.0 \mathrm{~b}$ & $3.0 \mathrm{a}$ & $3.6 \mathrm{~b}$ & $4.8 \mathrm{c}$ & $5.0 \mathrm{c}$ \\
\hline 13 Apr. 1999 & $4.6 \mathrm{a}$ & $5.4 \mathrm{~b}$ & $6.5 \mathrm{c}$ & $7.5 \mathrm{~d}$ & $8.4 \mathrm{e}$ \\
\hline 10 May 1999 & $4.0 \mathrm{a}$ & $4.8 \mathrm{~b}$ & $6.8 \mathrm{c}$ & $8.1 \mathrm{~d}$ & $7.5 \mathrm{~d}$ \\
\hline 14 June 1999 & $4.8 \mathrm{ab}$ & $5.4 \mathrm{bc}$ & $6.1 \mathrm{~d}$ & $5.9 \mathrm{~cd}$ & $4.5 \mathrm{a}$ \\
\hline 10 July 1999 & $2.0 \mathrm{a}$ & $2.1 \mathrm{a}$ & $2.4 \mathrm{ab}$ & $2.9 \mathrm{c}$ & $2.6 \mathrm{bc}$ \\
\hline 10 Aug. 1999 & $1.1 \mathrm{a}$ & $1.1 \mathrm{a}$ & $1.1 \mathrm{a}$ & $1.1 \mathrm{a}$ & $1.0 \mathrm{a}$ \\
\hline 14 Sept. 1999 & $6.4 \mathrm{a}$ & $6.6 \mathrm{a}$ & $7.6 \mathrm{~b}$ & $7.9 \mathrm{~b}$ & $7.6 \mathrm{~b}$ \\
\hline 14 Oct. 1999 & $5.1 \mathrm{a}$ & $5.5 \mathrm{a}$ & $7.1 \mathrm{~b}$ & $8.4 \mathrm{c}$ & $9.0 \mathrm{~d}$ \\
\hline 12 Nov. 1999 & $5.3 \mathrm{a}$ & $5.1 \mathrm{a}$ & $7.4 \mathrm{~b}$ & $8.3 c$ & $8.9 \mathrm{~d}$ \\
\hline 20 Dec. 1999 & $2.5 \mathrm{a}$ & $3.0 \mathrm{a}$ & $5.4 \mathrm{~b}$ & $6.8 c$ & $8.1 \mathrm{~d}$ \\
\hline 18 Jan. 2000 & $1.9 \mathrm{a}$ & $2.0 \mathrm{a}$ & $2.8 \mathrm{~b}$ & $4.6 \mathrm{c}$ & $6.1 \mathrm{~d}$ \\
\hline 26 Feb. 2000 & $1.0 \mathrm{a}$ & $1.1 \mathrm{a}$ & $2.0 \mathrm{~b}$ & $2.9 \mathrm{c}$ & $3.8 \mathrm{~d}$ \\
\hline 15 Mar. 2000 & $1.5 \mathrm{a}$ & $1.6 \mathrm{a}$ & $2.5 \mathrm{~b}$ & $3.9 c$ & $5.3 \mathrm{~d}$ \\
\hline 12 Apr. 2000 & $2.6 \mathrm{a}$ & $2.9 \mathrm{a}$ & $4.5 \mathrm{~b}$ & $6.4 c$ & $7.6 \mathrm{~d}$ \\
\hline 17 May 2000 & $3.9 \mathrm{a}$ & $4.0 \mathrm{a}$ & $5.6 \mathrm{~b}$ & $7.9 \mathrm{c}$ & $7.8 \mathrm{c}$ \\
\hline 14 June 2000 & $2.6 \mathrm{a}$ & $3.0 \mathrm{a}$ & $5.9 \mathrm{~b}$ & $7.0 \mathrm{c}$ & $7.3 \mathrm{c}$ \\
\hline
\end{tabular}

${ }^{2}$ Visually rated on a scale from 1 to $9(1=$ straw brown; $9=$ dark green $)$.

$y$ inch $=2.54 \mathrm{~cm}$.

'Within rows, means followed by same letter are not significantly different according to Duncan's multiple range test $(P=0.05)$.

plots. Fewer weeds on the composted plots were likely due to the higher plant densities and percent cover compared to the control and fertilized plots. Occasionally, mushrooms were observed growing in the 3 -inch plots; however, they were short-lived and considered a minor nuisance.

The compost treatments provided a much longer turf response than the one-time fertilizer treatment. At the study's end, 14 June 2000, all compost 
Table 3. Mean density of kentucky bluegrass on various dates after seeding on 2 Sept. 1998 as influenced by fertilizer and three rates of incorporated compost.

\begin{tabular}{|c|c|c|c|c|c|}
\hline \multirow[b]{3}{*}{ Date } & \multicolumn{5}{|c|}{ Mean density $(\%)^{\mathrm{z}}$} \\
\hline & \multirow[b]{2}{*}{ Control } & \multirow[b]{2}{*}{ Fertilizer } & \multicolumn{3}{|c|}{ Depth of applied compost (inches) } \\
\hline & & & 1 & 2 & 3 \\
\hline 14 Sept. 1999 & $4.8 \mathrm{a}^{\mathrm{x}}$ & $6.1 \mathrm{a}$ & $7.8 \mathrm{~b}$ & $8.3 \mathrm{~b}$ & $8.0 \mathrm{~b}$ \\
\hline 14 Oct. 1999 & $4.0 \mathrm{a}$ & $5.5 \mathrm{~b}$ & $8.3 \mathrm{c}$ & $9.0 \mathrm{c}$ & $9.0 \mathrm{c}$ \\
\hline 12 Nov. 1999 & $2.8 \mathrm{a}$ & $4.0 \mathrm{~b}$ & $7.9 \mathrm{c}$ & $9.0 \mathrm{~d}$ & $9.0 \mathrm{~d}$ \\
\hline 20 Dec. 1999 & $3.3 \mathrm{a}$ & $4.6 \mathrm{~b}$ & $7.4 \mathrm{~d}$ & $8.4 \mathrm{c}$ & $8.8 \mathrm{c}$ \\
\hline 15 Mar. 2000 & $2.9 \mathrm{a}$ & $3.9 \mathrm{a}$ & $6.1 \mathrm{~b}$ & $6.8 \mathrm{bc}$ & $7.8 \mathrm{c}$ \\
\hline 12 Apr. 2000 & $2.9 \mathrm{a}$ & $3.9 \mathrm{a}$ & $6.1 \mathrm{~b}$ & $6.8 \mathrm{bc}$ & $7.8 \mathrm{c}$ \\
\hline 17 May 2000 & $2.3 \mathrm{a}$ & $2.8 \mathrm{a}$ & $5.5 \mathrm{~b}$ & $7.9 \mathrm{c}$ & $9.0 \mathrm{~d}$ \\
\hline 14 June 2000 & $2.8 \mathrm{a}$ & $3.0 \mathrm{a}$ & $6.8 \mathrm{~b}$ & $8.9 c$ & $9.0 \mathrm{c}$ \\
\hline
\end{tabular}

Table 4. Mean percent weeds in kentucky bluegrass plots on various dates after seeding on 2 Sept. 1998 as influenced by fertilizer and three rates of incorporated compost.

\begin{tabular}{lccccc}
\hline & \multicolumn{5}{c}{ Mean weeds (\%) } \\
\cline { 2 - 6 } Date & Control & Fertilizer & $\mathbf{1}$ & $\mathbf{2}$ & $\mathbf{3}$ \\
\hline 22 Oct. 1998 & $16.8 \mathrm{ab}$ & $12.8 \mathrm{ab}$ & $10.3 \mathrm{ab}$ & $17.5 \mathrm{~b}$ & $9.3 \mathrm{a}$ \\
13 Apr. 1999 & $6.3 \mathrm{ab}$ & $12.5 \mathrm{c}$ & $10.0 \mathrm{bc}$ & $11.3 \mathrm{bc}$ & $4.3 \mathrm{a}$ \\
10 May 1999 & $9.5 \mathrm{~b}$ & $10.0 \mathrm{~b}$ & $10.3 \mathrm{~b}$ & $8.0 \mathrm{~b}$ & $1.5 \mathrm{a}$ \\
14 June 1999 & $2.0 \mathrm{c}$ & $1.0 \mathrm{abc}$ & $1.5 \mathrm{bc}$ & $0.3 \mathrm{a}$ & $0.5 \mathrm{ab}$ \\
10 July 1999 & $2.0 \mathrm{~b}$ & $0.8 \mathrm{a}$ & $0.8 \mathrm{a}$ & $0.3 \mathrm{a}$ & $0.0 \mathrm{a}$ \\
10 Aug. 1999 & $2.0 \mathrm{~b}$ & $0.8 \mathrm{a}$ & $0.8 \mathrm{a}$ & $0.3 \mathrm{a}$ & $0.0 \mathrm{a}$ \\
14 Sept. 1999 & $5.0 \mathrm{~b}$ & $2.4 \mathrm{a}$ & $1.1 \mathrm{a}$ & $0.5 \mathrm{a}$ & $0.0 \mathrm{a}$ \\
14 Oct. 1999 & $4.3 \mathrm{c}$ & $2.9 \mathrm{bc}$ & $0.9 \mathrm{ab}$ & $0.4 \mathrm{a}$ & $0.4 \mathrm{a}$ \\
12 Nov. 1999 & $4.3 \mathrm{c}$ & $2.9 \mathrm{bc}$ & $0.9 \mathrm{ab}$ & $0.4 \mathrm{a}$ & $0.4 \mathrm{a}$ \\
12 Apr. 2000 & $3.0 \mathrm{~b}$ & $1.5 \mathrm{a}$ & $1.3 \mathrm{a}$ & $0.5 \mathrm{a}$ & $0.8 \mathrm{a}$ \\
17 May 2000 & $5.0 \mathrm{c}$ & $3.0 \mathrm{~b}$ & $1.5 \mathrm{ab}$ & $0.3 \mathrm{a}$ & $0.0 \mathrm{a}$ \\
14 June 2000 & $2.0 \mathrm{c}$ & $1.3 \mathrm{bc}$ & $1.0 \mathrm{~b}$ & $0.5 \mathrm{ab}$ & $0.0 \mathrm{a}$
\end{tabular}

${ }^{2} 1$ inch $=2.54 \mathrm{~cm}$.

Within rows, means followed by same letter are not significantly different according to Duncan's multiple range test $(P=0.05)$

treatments had significantly greater percent cover, color, and density than the fertilizer treatment and the control. Thus, the compost provided a longterm supply of nutrients. Loschinkohl and Boehm (2001) also found that incorporated biosolid compost provided long-term supply of nutrients to turfgrass.

The observed turfgrass responses were in part due to the chemical differences in the soils created by the various treatments (Table 5 ). On most dates, the 2 -inch and 3 -inch plots had significantly higher mean levels of $\mathrm{NO}_{3}-$ $\mathrm{N}, \mathrm{NH}_{4}-\mathrm{N}$, Total- $\mathrm{N}$, organic matter, $\mathrm{K}$, and available $\mathrm{P}$. For most analytes, the control, l-inch, and fertilized plots were similar. Mean soluble salt levels, represented by electrical conductivity, were initially higher for the compost treatments but then became similar for all treatments. On 2 Sept. 1998, just prior to seeding, soluble salt levels significantly increased as the compost rate increased (Table 5). For the 3inch plots, the mean soluble salt level fell within the "strongly saline" range [1.6-3.2 dS. $\mathrm{m}^{-1}$ for 1 soil:2 water extract method (Dellavalle, 1992)]. The 2 -inch plots had a mean salt level that fell within the "saline" range $\left(1.2-1.6 \mathrm{dS} \cdot \mathrm{m}^{-1}\right)$ and the 1 -inch plots fell within the "very slightly saline" range $\left(0.4-0.8 \mathrm{dS} \cdot \mathrm{m}^{-1}\right)$. Fertilized and control plots fell in the "negligible" salinity range $\left(<0.4 \mathrm{dS} \cdot \mathrm{m}^{-1}\right)$. Over time the 2 -inch and 3 -inch plots developed a higher $\mathrm{CEC}$ and a lower $\mathrm{pH}$. There were no obvious trends in the data for $\mathrm{K}, \mathrm{Mg}, \mathrm{Ca}$, and their percent saturations.
Despite having significantly higher amounts of $\mathrm{NO}_{3}-\mathrm{N}, \mathrm{NH}_{4}-\mathrm{N}$, $\mathrm{K}$, and available $\mathrm{P}$ compared to the control on 2 Sept. 1998, the 2 -inch and 3 -inch treatments gave a similar percent cover response on the first evaluation date, 26 Sept. 1998. The benefit of the additional available nutrients in the compost was likely countered by high soluble salt levels in the 2 -inch and 3 inch treatments (Table 5). Harivandi et al. (1992) classified kentucky bluegrass as sensitive to salinity and stated that it will have difficulty in establishment and maintenance at electrical conductivity values greater than $3 \mathrm{dS} \cdot \mathrm{m}^{-1}$ (saturated paste extract), which is approximately $1.0 \mathrm{dS} \cdot \mathrm{m}^{-1}$ (1 soil:2 water extract).

In addition, significantly higher concentrations of $\mathrm{NH}_{4}-\mathrm{N}$ in the compost-treated plots at time of seeding may have contributed to the delay in establishment. After about 6 weeks, the inhibiting factors subsided and the turfgrass growing in the compost-amended soil quickly established and began outperforming the one-time fertilized plots. Although seed establishment was inhibited on the composted plots, the inhibiting conditions did not cause significant seed or seedling death. Barker (1993) found similar results using perennial ryegrass seed on pure immature biosolid compost. When the compost was mixed with soil, Barker reported a slight increase in seed germination along with a dilution of total $\mathrm{N}$ supply. Barker determined that high levels of $\mathrm{NH}_{4}-\mathrm{N}$ (1000 to $2000 \mathrm{mg} \cdot \mathrm{kg}^{-1}$ ) in the compost inhibited seedling establishment. In a related two-part study, O'Brien and Barker (1996a, 1996b) assessed perennial ryegrass germination in flats of pure biosolid compost that had levels of $\mathrm{NH}_{4}-\mathrm{N}$ equaling 1150 or $2300 \mathrm{mg} \cdot \mathrm{kg}^{-1}$ (dry weight) added from ammonium sulfate. They determined that high $\mathrm{NH}_{4}-\mathrm{N}$ and salt levels, typical of immature composts, inhibited seed germination. They concluded that seeding should be delayed for 7-14 $\mathrm{d}$ after applying immature compost. Over time, reductions in the $\mathrm{NH}_{4}-\mathrm{N}$ levels resulted in improved conditions for seed establishment.

Landschoot and McNitt (1994) studied kentucky bluegrass establishment from seed on soil amended with different composts. They found that biosolid compost from the Philadelphia Water Department showed the most dramatic increase in turfgrass cover during the establishment period-even 
Table 5. Mean soil test results from plots seeded with kentucky bluegrass on 2 Sept. 1998 as influenced by fertilizer and three rates of incorporated compost.

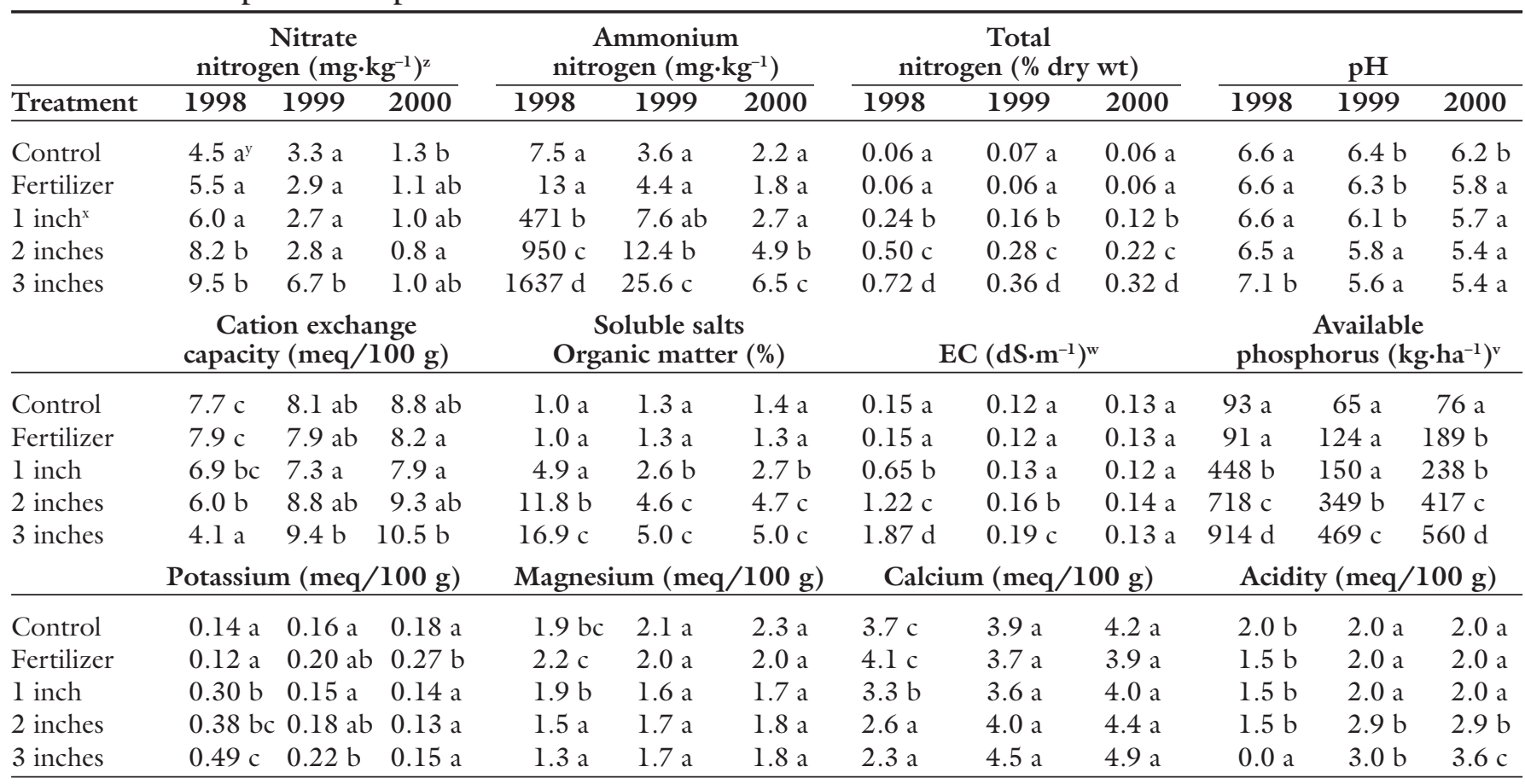

${ }^{\mathrm{z}} \mathrm{mg} \cdot \mathrm{kg}^{-1}=\mathrm{ppm}$.

Within columns of each analyte, means followed by same letter are not significantly different according to Duncan's multiple range test $(P=0.05)$.

${ }^{x} 1$ inch $=2.54 \mathrm{~cm}$

wEC $=$ electrical conductivity; $\mathrm{dS} \cdot \mathrm{m}^{-1}=\mathrm{mmho} / \mathrm{cm}$

${ }^{v} \mathrm{l} \mathrm{kg} \cdot \mathrm{ha}^{-1}=0.8922 \mathrm{lb} /$ acre.

better than the fertilizer treatment. High amounts of $\mathrm{NH}_{4}-\mathrm{N}(2000$ $\mathrm{mg} \cdot \mathrm{kg}^{-1}$ dry weight) and available $\mathrm{P}$ in the compost and improved soil physical properties were thought to be responsible for the response. They found that even though the pure biosolid compost had high levels of $\mathrm{NH}_{4}-\mathrm{N}$ and soluble salts $\left(\mathrm{EC}=4.2 \mathrm{dS} \cdot \mathrm{m}^{-1} ; 1\right.$ soil: 2 water extract method), they did not observe any inhibitions in seed germination or seedling establishment. Landschoot and McNitt (1994) concluded that the salts were diluted by incorporation of the compost into the soil.

Soluble salts in the 60 -d-cured compost equaled $4.72 \mathrm{dS} \cdot \mathrm{m}^{-1}$. Incorporating the compost into the soil also diluted the salt concentration (Table $5)$, however soluble salt levels in the compost-soil mix remained in the "strongly saline" and "saline" ranges for the 3-inch and 2-inch treatments, respectively. Although the compost was diluted by incorporating it into the soil, levels of soluble salts and $\mathrm{NH}_{4}^{-}$ $\mathrm{N}$ remained high enough to inhibit seedling establishment.

In a study using composted biosolids as a soil amendment for turf, Loschinkohl and Boehm (2001) found enhanced turfgrass seed establishment on compost-amended plots. They attributed this result to the additional available $\mathrm{N}$ and $\mathrm{P}$ introduced into the seedbed by the compost. In their study, plots were seeded $11 \mathrm{~d}$ after compost incorporation, however, in this study plots were seeded immediately after compost incorporation. The time between compost incorporation and seeding may have an influence on turfgrass establishment-especially if the compost is unstable or immature.

\section{Establishment study from sod}

Color and plant density were the main variables used to assess sod establishment. It was assumed that the plots with the highest color and density shortly after sodding were quickest to establish. One day after sodding, all plots had similar color, density, and no weeds. On 26 Sept. 1998, 24 d after treatment application, the plots that received the fertilizer treatment had significantly higher color and density ratings than other treatments (Tables 6 and 7). In addition, the color and density response was similar for all compost treatments and the control on 26 September. Thus, the sod established quickest for the fertilizer treatment. By 9 Oct. 1998, the fertilizer treatment and all compost treatments had similar color and density ratings and were significantly higher than the control treatment. After 9 Oct., the 1 -inch, 2 -inch, and 3 -inch treatments had significantly higher color and density ratings than either the control or fertilizer treatment. In general, color and density ratings were similar for the 2 -inch and 3 -inch treatments. This trend was interrupted during June, July, and Aug. 1999 because plants entered summer dormancy due to an extended drought. The turfgrass on the 3 -inch treatment and the control visibly entered dormancy earlier than all other treatments. Upon rewetting in Sept. 1999, the 3-inch plots performed similar to pre-drought levels.

For all dates, percent cover was $100 \%$ and there were no significant treatment differences. Significant differences for percent weeds did not occur until May 2000, however no trend was evident between treatments. Percent weeds ranged from 0 to $9 \%$, with most occurring near the end of the study. On a few dates, small mushrooms were observed growing mainly in the 3 -inch plots. The mushrooms were short-lived and considered a minor nuisance. 
Table 6. Mean color of kentucky bluegrass on various dates after sodding on 2 Sept. 1998 as influenced by fertilizer and three rates of incorporated compost.

\begin{tabular}{lccccc}
\hline & \multicolumn{5}{c}{ Mean color $(\%)^{\mathrm{z}}$} \\
\cline { 2 - 6 } Date & Control & Fertilizer & \multicolumn{1}{c}{ Depth of applied compost (inches) } \\
\cline { 2 - 6 } 3 Sept. 1998 & $8.0 \mathrm{a}^{\mathrm{x}}$ & $8.0 \mathrm{a}$ & $8.0 \mathrm{a}$ & $8.0 \mathrm{a}$ & $8.0 \mathrm{a}$ \\
26 Sept. 1998 & $7.5 \mathrm{ab}$ & $8.6 \mathrm{c}$ & $7.8 \mathrm{~b}$ & $7.4 \mathrm{ab}$ & $7.3 \mathrm{a}$ \\
9 Oct. 1998 & $7.1 \mathrm{a}$ & $8.6 \mathrm{~b}$ & $8.5 \mathrm{~b}$ & $8.8 \mathrm{~b}$ & $8.5 \mathrm{~b}$ \\
22 Oct. 1998 & $7.0 \mathrm{a}$ & $8.4 \mathrm{~b}$ & $8.8 \mathrm{c}$ & $9.0 \mathrm{~d}$ & $9.0 \mathrm{~d}$ \\
6 Nov. 1998 & $5.3 \mathrm{a}$ & $7.4 \mathrm{~b}$ & $8.1 \mathrm{c}$ & $9.0 \mathrm{~d}$ & $8.9 \mathrm{~d}$ \\
6 Dec. 1998 & $5.1 \mathrm{a}$ & $6.9 \mathrm{~b}$ & $7.4 \mathrm{c}$ & $8.6 \mathrm{~d}$ & $8.8 \mathrm{~d}$ \\
12 Mar. 1999 & $3.1 \mathrm{a}$ & $3.5 \mathrm{~b}$ & $4.0 \mathrm{c}$ & $4.6 \mathrm{~d}$ & $5.0 \mathrm{e}$ \\
13 Apr. 1999 & $4.0 \mathrm{a}$ & $4.9 \mathrm{~b}$ & $6.0 \mathrm{c}$ & $7.4 \mathrm{~d}$ & $8.8 \mathrm{e}$ \\
10 May 1999 & $4.0 \mathrm{a}$ & $4.9 \mathrm{~b}$ & $7.1 \mathrm{c}$ & $8.1 \mathrm{~d}$ & $7.5 \mathrm{~cd}$ \\
14 June 1999 & $3.5 \mathrm{a}$ & $4.5 \mathrm{~b}$ & $4.5 \mathrm{~b}$ & $4.1 \mathrm{~b}$ & $3.5 \mathrm{a}$ \\
10 July 1999 & $2.0 \mathrm{bc}$ & $2.1 \mathrm{c}$ & $2.1 \mathrm{c}$ & $1.8 \mathrm{ab}$ & $1.5 \mathrm{a}$ \\
10 Aug. 1999 & $1.0 \mathrm{a}$ & $1.0 \mathrm{a}$ & $1.0 \mathrm{a}$ & $1.0 \mathrm{a}$ & $1.0 \mathrm{a}$ \\
14 Sept. 1999 & $6.4 \mathrm{a}$ & $6.8 \mathrm{a}$ & $6.9 \mathrm{a}$ & $6.8 \mathrm{a}$ & $6.8 \mathrm{a}$ \\
14 Oct. 1999 & $6.0 \mathrm{a}$ & $5.9 \mathrm{a}$ & $7.3 \mathrm{~b}$ & $8.3 \mathrm{c}$ & $8.5 \mathrm{c}$ \\
12 Nov. 1999 & $3.5 \mathrm{a}$ & $4.3 \mathrm{a}$ & $6.4 \mathrm{~b}$ & $7.6 \mathrm{c}$ & $8.9 \mathrm{~d}$ \\
20 Dec. 1999 & $3.4 \mathrm{a}$ & $3.3 \mathrm{a}$ & $6.1 \mathrm{~b}$ & $7.4 \mathrm{c}$ & $7.6 \mathrm{c}$ \\
18 Jan. 2000 & $3.4 \mathrm{a}$ & $3.3 \mathrm{a}$ & $4.1 \mathrm{~b}$ & $5.0 \mathrm{c}$ & $5.3 \mathrm{c}$ \\
26 Feb. 2000 & $2.1 \mathrm{a}$ & $2.1 \mathrm{a}$ & $2.6 \mathrm{ab}$ & $2.9 \mathrm{~b}$ & $2.9 \mathrm{~b}$ \\
15 Mar. 2000 & $2.3 \mathrm{a}$ & $2.1 \mathrm{a}$ & $3.1 \mathrm{~b}$ & $4.0 \mathrm{c}$ & $4.4 \mathrm{~d}$ \\
12 Apr. 2000 & $3.5 \mathrm{a}$ & $3.5 \mathrm{a}$ & $6.0 \mathrm{~b}$ & $7.5 \mathrm{c}$ & $7.8 \mathrm{c}$ \\
17 May 2000 & $3.9 \mathrm{a}$ & $3.9 \mathrm{a}$ & $5.9 \mathrm{~b}$ & $6.9 \mathrm{c}$ & $7.5 \mathrm{~d}$ \\
14 June 2000 & $3.9 \mathrm{a}$ & $3.9 \mathrm{a}$ & $6.3 \mathrm{~b}$ & $7.4 \mathrm{c}$ & $7.8 \mathrm{~d}$ \\
\hline
\end{tabular}

${ }^{2}$ Visually rated on a scale from 1 to $9(1=$ straw brown; $9=$ dark green $)$.

${ }^{y} 1$ inch $=2.54 \mathrm{~cm}$.

'Within rows, means followed by same letter are not significantly different according to Duncan's multiple range test $(P=0.05)$.

Table 7. Mean density of kentucky bluegrass on various dates after sodding on 2 Sept. 1998 as influenced by fertilizer and three rates of incorporated compost.

\begin{tabular}{lccccc}
\hline & \multicolumn{5}{c}{ Mean density $(\%)^{\mathrm{z}}$} \\
\cline { 2 - 6 } Date & Control & Fertilizer & $\mathbf{1}$ & $\mathbf{2}$ & Depth of applied compost (inches) \\
\hline 3 Sept. 1998 & $7.5 \mathrm{a}^{\mathrm{x}}$ & $7.5 \mathrm{a}$ & $7.5 \mathrm{a}$ & $7.5 \mathrm{a}$ & $7.5 \mathrm{a}$ \\
26 Sept. 1998 & $7.4 \mathrm{a}$ & $8.6 \mathrm{~b}$ & $7.8 \mathrm{a}$ & $7.8 \mathrm{a}$ & $7.5 \mathrm{a}$ \\
9 Oct. 1998 & $7.8 \mathrm{a}$ & $8.6 \mathrm{~b}$ & $8.1 \mathrm{ab}$ & $8.6 \mathrm{~b}$ & $8.4 \mathrm{~b}$ \\
22 Oct. 1998 & $8.0 \mathrm{a}$ & $8.5 \mathrm{~b}$ & $8.9 \mathrm{bc}$ & $8.9 \mathrm{bc}$ & $9.0 \mathrm{c}$ \\
6 Nov. 1998 & $6.6 \mathrm{a}$ & $8.0 \mathrm{~b}$ & $8.8 \mathrm{c}$ & $9.0 \mathrm{c}$ & $8.8 \mathrm{c}$ \\
6 Dec. 1998 & $5.3 \mathrm{a}$ & $7.3 \mathrm{~b}$ & $7.5 \mathrm{~b}$ & $8.9 \mathrm{c}$ & $8.9 \mathrm{c}$ \\
12 Mar. 1999 & $5.3 \mathrm{a}$ & $6.0 \mathrm{~b}$ & $7.0 \mathrm{c}$ & $7.0 \mathrm{c}$ & $7.3 \mathrm{c}$ \\
13 Apr. 1999 & $6.0 \mathrm{a}$ & $6.0 \mathrm{a}$ & $6.4 \mathrm{~b}$ & $7.0 \mathrm{c}$ & $8.0 \mathrm{~d}$ \\
10 May 1999 & $2.1 \mathrm{a}$ & $3.6 \mathrm{~b}$ & $5.8 \mathrm{c}$ & $8.3 \mathrm{~d}$ & $9.0 \mathrm{e}$ \\
14 June 1999 & $3.0 \mathrm{a}$ & $4.9 \mathrm{~b}$ & $6.9 \mathrm{c}$ & $8.9 \mathrm{~d}$ & $9.0 \mathrm{~d}$ \\
10 July 1999 & $3.0 \mathrm{a}$ & $4.9 \mathrm{~b}$ & $6.9 \mathrm{c}$ & $8.9 \mathrm{~d}$ & $9.0 \mathrm{~d}$ \\
10 Aug. 1999 & $3.0 \mathrm{a}$ & $4.9 \mathrm{~b}$ & $9.0 \mathrm{c}$ & $8.9 \mathrm{~d}$ & $9.0 \mathrm{~d}$ \\
14 Sept. 1999 & $6.1 \mathrm{a}$ & $6.9 \mathrm{a}$ & $7.3 \mathrm{a}$ & $6.9 \mathrm{a}$ & $6.5 \mathrm{a}$ \\
14 Oct. 1999 & $5.6 \mathrm{a}$ & $6.0 \mathrm{ab}$ & $7.4 \mathrm{c}$ & $7.5 \mathrm{c}$ & $7.0 \mathrm{bc}$ \\
12 Nov. 1999 & $6.0 \mathrm{a}$ & $6.1 \mathrm{a}$ & $7.5 \mathrm{~b}$ & $8.1 \mathrm{bc}$ & $8.5 \mathrm{c}$ \\
20 Dec. 1999 & $5.6 \mathrm{a}$ & $5.6 \mathrm{a}$ & $7.3 \mathrm{~b}$ & $7.9 \mathrm{~b}$ & $7.9 \mathrm{~b}$ \\
15 Mar. 2000 & $5.9 \mathrm{a}$ & $6.0 \mathrm{a}$ & $6.1 \mathrm{a}$ & $6.8 \mathrm{a}$ & $6.9 \mathrm{a}$ \\
12 Apr. 2000 & $5.9 \mathrm{a}$ & $6.0 \mathrm{a}$ & $6.1 \mathrm{a}$ & $6.8 \mathrm{a}$ & $6.9 \mathrm{a}$ \\
17 May 2000 & $3.1 \mathrm{a}$ & $2.9 \mathrm{a}$ & $5.3 \mathrm{~b}$ & $7.6 \mathrm{c}$ & $8.8 \mathrm{~d}$ \\
14 June 2000 & $4.4 \mathrm{a}$ & $4.9 \mathrm{a}$ & $7.6 \mathrm{~b}$ & $8.5 \mathrm{c}$ & $8.9 \mathrm{c}$ \\
\hline
\end{tabular}

${ }^{2}$ Visually rated on a scale from 1 to 9 ( $1=$ no plants; 9 = maximum density).

y 1 inch $=2.54 \mathrm{~cm}$

'Within rows, means followed by same letter are not significantly different according to Duncan's multiple range test $(P=0.05)$.
Soil test results were similar to the establishment study from seed (Tables 8 and 5 ). The observed response of turfgrass grown in the compost treatments was in part due to chemical changes in the soil caused by the addition of compost. Chemical changes in the soil became greater as the compost rate increased. On most test dates, the 2 -inch and 3 -inch treatments had significantly higher levels of $\mathrm{NO}_{3}-\mathrm{N}, \mathrm{NH}_{4}-\mathrm{N}$, Total- $\mathrm{N}$, organic matter, $\mathrm{K}$, and available $\mathrm{P}$ compared to other treatments. Despite having significantly higher amounts of plant available nutrients compared to the control on 2 Sept. 1998, the 2 -inch and 3 -inch treatments gave a similar color and density response on the first evaluation date, 26 Sept. 1998. The benefit of the additional available nutrients in the compost was likely countered by high soluble salt levels in the 2 -inch and 3 -inch treatments at the time of sodding (Table 8). On 2 Sept. 1998, mean soluble salt levels were significantly higher for the 2 -inch and 3 -inch treatments. Both treatments had mean salt levels in the "strongly saline" range (Dellavalle, 1992). Mean salt levels for the 1 -inch plots were in the "very slightly saline" range. Fertilized and control plots were in the negligible salinity range. For most analytes, the control, 1 -inch, and fertilizer treatments were similar. By 10 Sept. 1999, the 2 -inch and 3 -inch treatments had developed a higher $\mathrm{CEC}$ and lower $\mathrm{pH}$. Although some treatments were significantly different on some test dates for $\mathrm{K}, \mathrm{Mg}$, and $\mathrm{Ca}$, there were no obvious trends.

Higher concentrations of $\mathrm{NH}_{4}-\mathrm{N}$ in the composted plots at the time of sodding may have contributed to the delayed response; however, there is little research on the effects that high soil $\mathrm{NH}_{4}-\mathrm{N}$ has on establishment of sodded turfgrass.

By 9 Oct. 1998, the inhibitory levels of soil salinity and $\mathrm{NH}_{4}-\mathrm{N}$ were likely reduced and the composted plots performed as well as the fertilized plots. By 22 Oct. 1998, the composted plots outperformed the fertilized and control plots.

The 2 -inch and 3 -inch treatments provided excellent color and density for the duration of the study despite not receiving any fertilizer. Thus, the compost provided a relatively longterm supply of nutrients compared to the one-time fertilizer treatment. 
Table 8. Mean soil test results from plots sodded with kentucky bluegrass on 2 Sept. 1998 as influenced by fertilizer and three rates of incorporated compost.

\begin{tabular}{|c|c|c|c|c|c|c|c|c|c|c|c|c|}
\hline \multirow[b]{2}{*}{ Treatment } & \multicolumn{3}{|c|}{$\begin{array}{c}\text { Nitrate } \\
\text { nitrogen }\left(\mathrm{mg} \cdot \mathrm{kg}^{-1}\right)^{\mathrm{z}}\end{array}$} & \multicolumn{3}{|c|}{$\begin{array}{c}\text { Ammonium } \\
\text { nitrogen }\left(\mathrm{mg} \cdot \mathrm{kg}^{-1}\right)\end{array}$} & \multicolumn{3}{|c|}{$\begin{array}{c}\text { Total } \\
\text { nitrogen }(\% \text { dry wt) }\end{array}$} & \multicolumn{3}{|c|}{$\mathrm{pH}$} \\
\hline & 1998 & 1999 & 2000 & 1998 & 1999 & 2000 & 1998 & 1999 & 2000 & 1998 & 1999 & 2000 \\
\hline Fertilizer & $4.1 \mathrm{a}$ & $3.0 \mathrm{a}$ & $4.4 \mathrm{a}$ & $12.4 \mathrm{a}$ & $5.8 \mathrm{a}$ & $3.3 \mathrm{a}$ & $0.07 \mathrm{a}$ & $0.06 \mathrm{a}$ & $0.09 \mathrm{a}$ & $6.7 \mathrm{a}$ & $6.2 \mathrm{~b}$ & $5.9 \mathrm{a}$ \\
\hline 1 inch $^{x}$ & $4.7 \mathrm{a}$ & $3.7 \mathrm{ab}$ & $4.6 \mathrm{a}$ & $419 \mathrm{~b}$ & $16.2 \mathrm{bc}$ & $9.1 \mathrm{~b}$ & $0.21 \mathrm{a}$ & $0.14 \mathrm{a}$ & $0.18 \mathrm{~b}$ & $6.7 \mathrm{a}$ & $6.1 \mathrm{~b}$ & $5.8 \mathrm{a}$ \\
\hline 2 inches & $7.3 \mathrm{~b}$ & $5.1 \mathrm{~b}$ & $6.7 \mathrm{a}$ & $1305 \mathrm{c}$ & $15.3 \mathrm{bc}$ & $10.1 \mathrm{~b}$ & $0.55 \mathrm{~b}$ & $0.33 \mathrm{~b}$ & $0.27 \mathrm{c}$ & $6.8 \mathrm{a}$ & $5.7 \mathrm{a}$ & $5.4 \mathrm{a}$ \\
\hline & \multicolumn{3}{|c|}{$\begin{array}{c}\text { Cation exchange } \\
\text { capacity (meq/100 g) }\end{array}$} & \multicolumn{3}{|c|}{$\begin{array}{c}\text { Soluble salts } \\
\text { Organic matter (\%) }\end{array}$} & \multicolumn{3}{|c|}{$\mathrm{EC}\left(\mathrm{dS} \cdot \mathrm{m}^{-1}\right)^{\mathrm{w}}$} & \multicolumn{3}{|c|}{$\begin{array}{c}\text { Available } \\
\text { phosphorus }\left(\mathrm{kg} \cdot \mathrm{ha}^{-1}\right)^{\mathrm{v}}\end{array}$} \\
\hline Con & $8.4 \mathrm{a}$ & $7.3 \mathrm{a}$ & $6.9 \mathrm{a}$ & $1.7 \mathrm{a}$ & $1.1 \mathrm{a}$ & $1.8 \mathrm{a}$ & $0.16 \mathrm{a}$ & $0.11 \mathrm{a}$ & $0.15 \mathrm{a}$ & $6 a$ & $88 \mathrm{a}$ & $87 \mathrm{a}$ \\
\hline Fertilizer & $8.0 \mathrm{a}$ & $7.5 \mathrm{a}$ & $7.5 \mathrm{ab}$ & $1.4 \mathrm{a}$ & $1.1 \mathrm{a}$ & $1.7 \mathrm{a}$ & $0.14 \mathrm{a}$ & $0.11 \mathrm{a}$ & $0.12 \mathrm{a}$ & $126 \mathrm{a}$ & $160 \mathrm{ab}$ & $175 \mathrm{~b}$ \\
\hline 1 inch & $6.8 \mathrm{a}$ & $7.7 \mathrm{a}$ & $8.2 \mathrm{bc}$ & $5.7 \mathrm{a}$ & $2.7 \mathrm{~b}$ & $3.2 \mathrm{~b}$ & $0.52 \mathrm{a}$ & $0.14 \mathrm{~b}$ & $0.16 \mathrm{ab}$ & $39 \mathrm{~b}$ & $274 \mathrm{~b}$ & $286 \mathrm{c}$ \\
\hline Control & $0.10 \mathrm{a}$ & $0.22 \mathrm{a}$ & $0.29 \mathrm{bc}$ & $2.37 \mathrm{~b}$ & $1.72 \mathrm{ab}$ & $1.57 \mathrm{abc}$ & $4.4 \mathrm{bc}$ & $3.3 \mathrm{a}$ & $3.1 \mathrm{a}$ & $1.5 \mathrm{a}$ & $2.0 \mathrm{a}$ & $2.0 \mathrm{a}$ \\
\hline Fertilizer & $0.09 \mathrm{a}$ & $0.23 \mathrm{a}$ & $0.30 \mathrm{c}$ & $2.35 \mathrm{~b}$ & $1.87 \mathrm{~b}$ & $1.72 \mathrm{bc}$ & $4.6 \mathrm{c}$ & $3.5 \mathrm{a}$ & $3.4 \mathrm{a}$ & $1.0 \mathrm{a}$ & $2.0 \mathrm{a}$ & $2.1 \mathrm{ab}$ \\
\hline 1 inch & $0.26 \mathrm{~b}$ & $0.20 \mathrm{a}$ & $0.23 \mathrm{a}$ & $1.90 \mathrm{ab}$ & $1.75 \mathrm{ab}$ & $1.80 \mathrm{c}$ & $3.7 \mathrm{abc}$ & $3.8 \mathrm{ab}$ & $3.9 \mathrm{~b}$ & $1.0 \mathrm{a}$ & $2.0 \mathrm{a}$ & $2.4 \mathrm{ab}$ \\
\hline 2 inches & $0.41 \mathrm{c}$ & $0.25 \mathrm{a}$ & $0.24 \mathrm{ab}$ & $1.77 \mathrm{a}$ & $1.67 \mathrm{ab}$ & $1.50 \mathrm{ab}$ & $3.0 \mathrm{a}$ & $4.6 \mathrm{c}$ & $4.0 \mathrm{~b}$ & $0.5 \mathrm{a}$ & $2.5 \mathrm{~b}$ & $2.8 \mathrm{bc}$ \\
\hline 3 inches & $0.43 \mathrm{c}$ & $0.26 \mathrm{a}$ & $0.23 \mathrm{a}$ & $1.75 \mathrm{a}$ & $1.45 \mathrm{a}$ & $1.35 \mathrm{a}$ & $3.2 \mathrm{ab}$ & $4.3 \mathrm{bc}$ & $4.0 \mathrm{~b}$ & $1.5 \mathrm{a}$ & $2.6 \mathrm{c}$ & $3.3 \mathrm{c}$ \\
\hline
\end{tabular}

${ }^{2} \mathrm{mg} \cdot \mathrm{kg}^{-1}=\mathrm{ppm}$.

Within columns of each analyte, means followed by same letter are not significantly different according to Duncan's multiple range test $(P=0.05)$.

${ }^{x} 1$ inch $=2.54 \mathrm{~cm}$

wEC = electrical conductivity; $\mathrm{dS} \cdot \mathrm{m}^{-1}=\mathrm{mmho} / \mathrm{cm}$

${ }^{v} \mathrm{l} \mathrm{kg} \cdot \mathrm{ha}^{-1}=0.8922 \mathrm{lb} /$ acre.

\section{Conclusion}

Overall, the biosolid compost performed well as a soil amendment for turfgrass and provided a long-term supply of plant nutrients. The 2 -inch and 3 -inch depths of compost appeared to be the better incorporation rates for the soil and compost used in the study. Despite being diluted with soil, the compost caused a 2 to 3 -week delay in seed and sod establishment. High salinity and excessive $\mathrm{NH}_{4}-\mathrm{N}$ levels in the compost at the time of establishment were likely the main causes of the inhibition. After the 2 to 3 -week period, the compost-amended plots generally outperformed the one-time fertilized plots in turfgrass color and density. Turf managers may want to account for the delay in establishment when incorporating a 60 -d-cured compost.

\section{Literature cited}

Beard, J.B. 1973. Turfgrass science and culture. Prentice-Hall, Englewood Cliffs, N.J.

Barker, A.V. 1993. Municipal solid waste compost as a medium for sod-grown crops. HortScience 28(4):256 (Abstr.).

Boulter, J.I., G.J. Boland, and J.T. Trevors. 2002. Evaluation of compost for suppression of dollar spot (Sclerotinia homeocarpa) of turfgrass. Plant Dis. 86(4):405-410.

Dellavalle, N.B. (ed.). 1992. Determination of specific conductance in supernatant 1:2 soil:water solution, p. 44-50. In: Handbook on reference methods for soil analysis. Soil and Plant Anal. Council, Athens, Ga.

Craft, C.M. and E.B. Nelson. 1996. Microbial properties of composts that suppress damping off and root rot of creeping bentgrass caused by Pythium graminicola. Appl. Environ. Microbiol. 62:1550-1557.

Harivandi, M.A., J.D. Butler, and L. Wu. 1992. Salinity and turfgrass culture, p. 207-230. In: D.V. Waddington, R.N. Carrow, and R.C. Shearman (eds.). Turfgrass. Monogr. 32. ASA, CSSA, and SSSA, Madison, Wis.
Landschoot, P. and A. McNitt. 1994. Improving turf with compost. Biocycle 35(10):54-57.

Loschinkohl, C. and M.J. Boehm. 2001. Composted biosolids incorporation improves turfgrass establishment on disturbed urban soil and reduces leaf rust severity. HortScience 36(4):790-794.

Markham, T.D., J.W. Rimelspach, and M.J. Boehm. 1998. Compost-amended sand-based rootzone mixes and their impact on turf establishment. Agron. Abstr. 1998:141.

O'Brien, T.A. and A.V. Barker. 1996a. Evaluation of ammonium and soluble salts on grass sod production in compost. I. Addition of ammonium or nitrate salts. Commun. Soil Sci. Plant Anal. 27(1\&2):57-76.

O'Brien, T.A. and A.V. Barker. 1996b. Evaluation of ammonium and soluble salts on grass sod production in compost. II. Delaying seeding after compost application. Commun. Soil Sci. Plant Anal. 27(1\&2):77-85.

Sikora, L.J. and N.K. Enkiri. 1999. Growth of tall fescue in compost/fertilizer blends. Soil Sci. 164(1):62-69. 